\title{
Research Paper: Retrospective Analysis of Hanging Cases Between 2016 and 2020 in Urban India
}

\author{
Gururaj Biradar', Charan Kishor Shetty ${ }^{2 *}$ D, Pavanchand H. Shetty ${ }^{3}$, V Yogiraj ${ }^{1}$
}

1. Department of Forensic Medicine, Faculty of Medicine, Vijayanagar Institute of Medical Sciences, Bellary, India.

2. Department of Forensic Medicine, Faculty of Medicine, Universit of Sultan Zainal Abidin, KualaTerengganu, Malaysia.

3. Department of Forensic Medicine, Faculty of Medicine, Kasturba Medical College, Mangalore, Manipal Academy of Higher Education,

Manipal, India.

\begin{tabular}{|c|c|}
\hline $\begin{array}{l}\text { Use your device to scan } \\
\text { and read the article online }\end{array}$ & Citation Biradar G, Shetty CK, Shetty PH, Yogiraj V. Retrospective Analysis of Hanging Cases Between 2016 and 2020 in \\
\hline 口iritin & $\begin{array}{l}\text { Urban India. International Journal of Medical Toxicology and Forensic Medicine. 2021; 11(4):33924. https://doi.org/10.32598/ } \\
\text { ijmtfm.v11i4.33924 }\end{array}$ \\
\hline 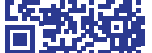 & doi https://doi.org/10.32598/ijmtfm.v11i4.33924 \\
\hline
\end{tabular}

Article info:

Received: 01 Feb 2021

First Revision: 10 Feb 2021

Accepted: 23 Jun 2021

Published: 21 Dec 2021

\section{Keywords:}

Hanging, Forensic pathology, Forensic autopsy, Asphyxia, Suicide, Autopsy, Ligature

\section{ABSTRACT}

Background: Death by hanging is a vital health hazard worldwide; it is classified as violent mechanical deaths resulting from asphyxia. The manner of death in hanging is suicide in the majority of the cases, and accidental hanging is less common, and homicidal hanging is still less common. The study was aimed towards analyzing sociodemographic patterns, precipitating factors for committing hanging at Vijayanagar Institute of Medical Sciences (VIMS), Ballari, India.

Methods: A retrospective study was conducted at the mortuary of VIMS, Ballari, Karnataka, India. From January 01, 2016, to December 31, 2020, 356 alleged hanging cases were brought to the mortuary for postmortem examination, and the cause of death was attributed to hanging. The necessary data were collected with the help of history, inquest reports, meticulous postmortem examination, etc. The results were obtained after tabulating and data analyzed with a cross-sectional study.

Results: Of 356 cases of hanging, the majority of the cases were in the age group of 31-40 years (140 patients; i.e., 39.32\%). Male preponderance was detected in $235(66 \%)$ cases, and most victims have married 199(56\%) subjects. Concerning seasonal variation, we noted that the maximum number of suicides by hanging was reported in July to September 141(39.60\%). Out of 356 hanging cases, 178(50\%) were employed. The predisposing factor was Chronic illness in $136(38.20 \%$ ) cases, followed by financial stress and psychological problems in $120(33.70 \%)$ and 50(14.04\%) cases, respectively. Most of the victims belonged to the Hindu religion, 290(82\%) cases. Moreover, 320(90\%) of cases had no suicide note.

Conclusion: Hanging is challenging to prevent due to numerous concomitant factors, but psychological counseling, economic support, and education can reduce the incidence of hanging.

\footnotetext{
* Corresponding Author:

Charan Kishor Shetty, MD.

Address: Department of Forensic Medicine, Faculty of Medicine, Universit of Sultan Zainal Abidin, KualaTerengganu, Malaysia.

Tel: +60 (19) 9785536

E-mail: charanshetty768@gmail.com
} 


\section{Introduction}

H

anging is classified as a violent asphyxial death caused by body suspension by a ligature encircles the neck, bodyweight being the constricting force [1]. In hanging cases, the manner of death is almost always suicide or accident, rarely homicide [2]. Considering the standard method of committing suicide, hanging is the most common, followed by fall from height, firearm (in men), and poisoning (in women) [3-5]. Hanging is preferred since it produces painless and rapid death and can occur even with partial suspension [4]. Hanging is classified as complete and incomplete when the body is found completely suspended from above. It is called full hanging; if some part of the body touches the ground, it is called incomplete or partial hanging [6]. Death by hanging occurs due to different mechanisms, including stretching the carotid complex, causing a reflex of cardiac inhibition, venous and arterial occlusion, airway obstruction, the disruption of the spinal cord, and so on [7]. According to the latest report of the National Crime Records Bureau (NCRB), in India, in 2019, 53.6\% of the total cases of suicide 2019 were committed by resorting to the mean of hanging compared to $51.5 \%$ in 2018. In 2019, 74629 persons committed suicide by hanging themselves to roofs or other support systems, while the frequency of suicide committed this way in 2018 was $51.5 \%$, with 69,306 suicides committed through the hanging [8]. Thus, this descriptive-retrospective study was performed to assess data on hanging cases and document the characteristics of death cases resulting from hanging.

\section{Materials and Methods}

The present retrospective study consists of hanging cases brought for postmortem examination at the mortuary of Vijayanagar Institute of Medical Sciences (VIMS), Bellary, India. The study was conducted between January 01, 2016, to December 31, 2020. In our center, 356 cases of hanging were recorded between January 01,2016 , to December 31, 2020. After reviewing case papers, inquest reports, and postmortem reports, the cases were studied to determine the incidence of asphyxial deaths due to hanging respecting age group, gender, occupation, month, predisposing factors, marital status, etc. Finally, the obtained data were tabulated and analyzed.

The inclusion criterion consisted of Autopsy on all medicolegal cases of asphyxial deaths due to hanging. The exclusion criteria were all violent asphyxial deaths other than hanging; birth asphyxia; sudden natural deaths, The presence of an advanced decomposition state. SPSS v. 27 was used for data analysis. Furthermore, the collected results were presented as frequency and percentage in figures and tables.

\section{Results}

In our study, of the 356 cases of hanging, the majority of the victims were $31-40$ years; $140(39.32 \%)$ cases, followed by 21-30 years $68(19.10 \%)$ cases, and 11-20 years 55 (15.44\%) cases (Figure1). Considering the gender-wise distribution, most hanging cases, $235(66 \%)$, were males (Figure 2). Regarding the marital status of the victims, almost 199(56\%) of the victims of hanging were married (Figure 3). Besides, the maximum number of cases, 141(39.60\%), were reported in July to September, April to June $90(25.28 \%)$ cases closely followed by October to December 75(21.06\%) cases (Figure 4). Most hanging cases, $226(60 \%)$, came from the urban locality (Table 1$)$.

By occupation, most of the deceased were employed $178(50 \%)$ cases, closely followed by $63(17.69 \%)$ cases of unemployed, 50(14.04\%) cases were housewives, $43(12.07 \%)$ students, and only $22(6.17 \%)$ cases were of agriculturist (Figure 5). Moreover, we found that the predisposing factor for suicide by hanging was due to chronic illness $136(38.20 \%)$ cases, financial stress in $120(33.70 \%)$ cases, psychological disorders in $50(14.04 \%)$ cases, chronic alcoholism in 40(11.23\%) cases, and substance abuse was a contributing factor in only $10(2.80 \%)$ cases (Figure 6).

In our study, of a total of 356 hanging cases, 290(82\%) cases belonged to the Hindu religion, while 55(15\%) cases were Muslims (Figure 7). In most cases, 247(69.38\%) in our study belonged to the lower socioeconomic status, followed by middle class $102(28.65 \%)$ of total cases (Table 2 ). Out

Table 1. Locality distribution in hanging cases $(n=356)$

\begin{tabular}{cc}
\hline Local & No. \\
\hline Urban & 226 \\
Rural & 130 \\
\hline
\end{tabular}




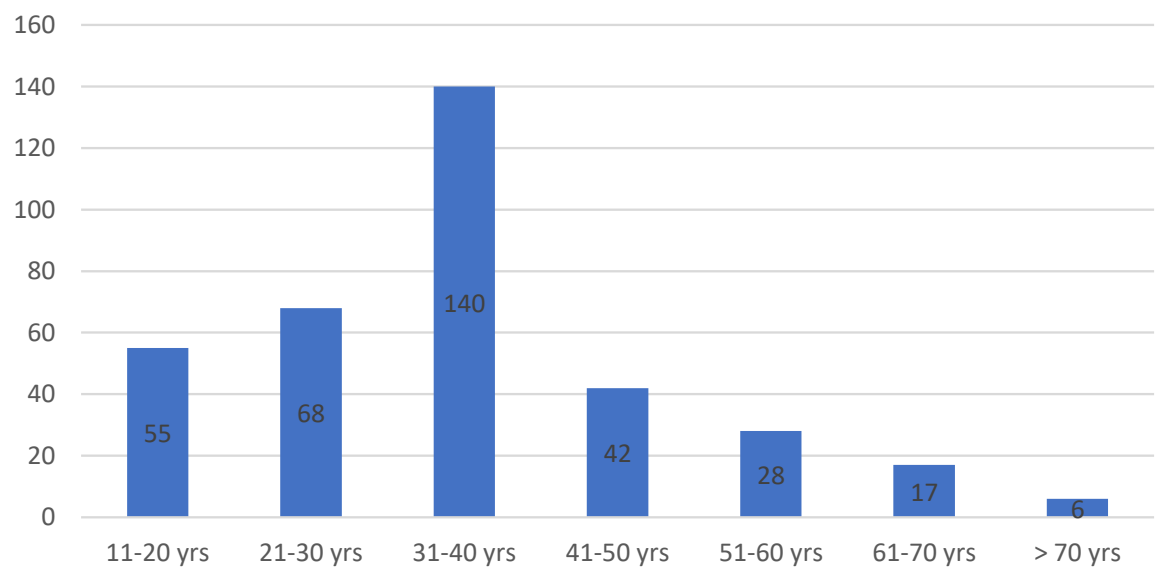

Figure 1. Age wise distribution of hanging victims $(n=356)$

of the 356 cases, the majority of victims, $277(77.80 \%$ ), belong to the nuclear family, while the remaining $79(22.19 \%)$ cases belonged to the joint family (Table 3 ).

In our study, the morning was the most preferred time for committing suicide accounting for $109(30.61 \%)$ cases, followed by $88(24.71 \%$ ) cases in the night and $85(23.87 \%)$ cases in the evening. (Table 4). In our study, most of the cases 320(90\%) cases had no suicide note (Figure 8).

\section{Discussion}

Suicide is among the leading causes of death in the world.1 Asian continent accounts for approximately $60 \%$ of world suicides, with China, India, and Japan accounting for about $40 \%$ of world suicides. Higher suicide rates $(>13.0 / 100$ 000) were recorded in Bangladesh, China, Hong Kong, Japan, South Korea, Sri Lanka, and Taiwan. Muslim countries (e.g., Iran, Pakistan, Saudi Arabia, \& Turkey) had a meager rate of suicide cases $(<6.5 / 100000)$; a reason for that may be due to stigmatization and legal sanctions against suicide leading to underreporting [1-8].
In this study, the cases were divided into 7 age groups. Of the 356 cases of hanging, the majority of the victims were 31-40 years, i.e., $140(39.32 \%)$ cases, followed by $21-30$ years $68(19.10 \%)$ cases and $11-20$ years; $55(15.44 \%)$ cases (Figure 1). Numerous studies indicated that productive younger age groups are commonly vulnerable. Accordingly, Waghmare et al. [9] reported that the most affected age group was between 21 and 30 years. Ashok Kumar et al. [10] mentioned the age range of the victims from 11-40 years. They also reported that the victims were under increased pressure due to the burdens of life. Reddy et al. [11] stated that asphyxial deaths were more in the age group of 21-30 years (34.93\%), followed by $11-20$ years $(20.10 \%)$ and $31-40$ years (17.80\%), respectively. However, Tanuj [12] mentioned that the third to fifth decades were the most affected age groups, accounting for $75.7 \%(n=53)$ of the total hanging deaths, i.e., almost similar in our study were joint age group was 31-40 years. The hanging victims tend to be of young working-age consistent with the results of Abd-Elwahab Hassan et al. [13] and Üzün and colleagues [14]. Suicide by hanging was also the most common method across all age groups [9-14].

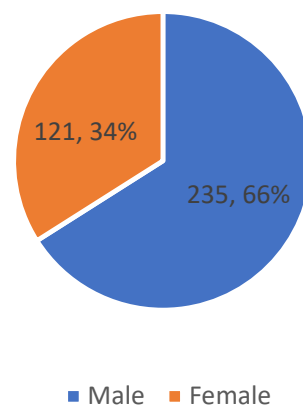

Figure 2. Sex wise distribution of hanging victims $(n=356)$ International Journal of
Medical Toxicology \& Forensic Medicine 


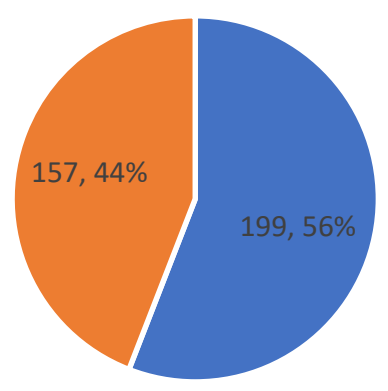

- Married - Unmarried

Figure 3. Marital status of hanging victims $(n=356)$

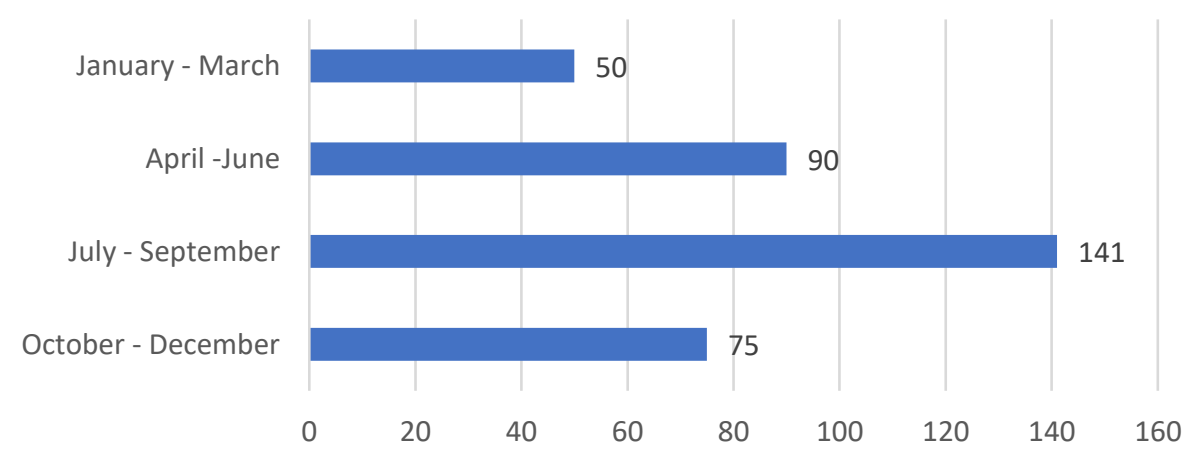

Figure 4. Hanging cases according to months $(n=356)$

Considering the gender-wise distribution, most hanging cases, 235(66\%) cases were males. The male-Female ratio was about 2:1 (Figure 2). Byard et al. [15] reported violent death is more commonly associated with men. Similar findings were demonstrated by Tanuj Kanchan [12], as the majority of the victims were males $(\mathrm{n}=53,75.7 \%)$. Sharija et al. [16] mentioned that most male victims were manual laborers (45\%). Reddy et al. [11] mentioned that the incidences of asphyxial death among males and in females were 259(59.14\%) and 179(40.86\%), in sequence. Studies in Thailand revealed that hanging was the most common means of suicide for both genders, with a higher percentage of men than women [17]. The study conducted at our hospital and authors' study at respective places highlighted correlation between the male and female pattern affected [9-17].

Regarding the marital status of the victims, almost 199 cases (56\%) of the victims of hanging were married (Figure 3). Similar findings were noted by Waghmare et al. [9]; they mentioned that the prevalence of suicide was higher in married individuals. He noted that out of 21 married women, 10 women had committed suicide within 07 years of marriage. However, Sharija et al. [16] mentioned that marriage is not a protective factor, particularly for the males in Kerala, unlike western data, where $55.8 \%$ of victims were married.

Table 2. Socioeconomic status of the study subjects $(n=356)$

\begin{tabular}{cl}
\hline $\begin{array}{c}\text { Socio-Economic } \\
\text { Status }\end{array}$ & No. \\
\hline Upper & 07 \\
Middle & 102 \\
\hline Lower & 247 \\
\hline & $\begin{array}{l}\text { International Journal of } \\
\text { Medical Toxicology \& Forensic Medicin }\end{array}$
\end{tabular}


Table 3. Distribution according to type of family

\begin{tabular}{cc}
\hline Type of Family & No. \\
\hline Nuclear & 277 \\
Non-Nuclear & 79 \\
\hline & $\begin{array}{l}\text { International Journal of } \\
\text { Medical Toxicology E Forensic Medicine }\end{array}$
\end{tabular}

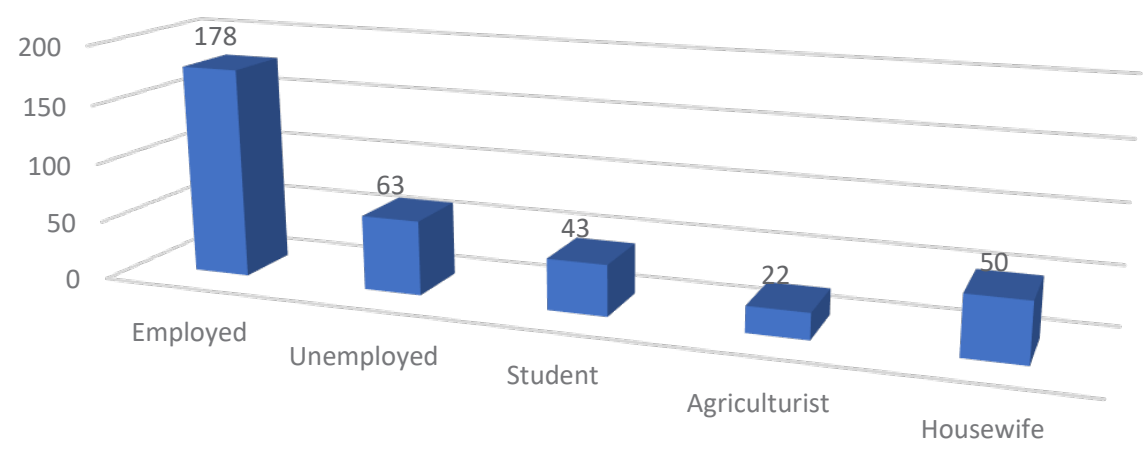

Figure 5. Occupation wise distribution of Hanging victims $(n=356)$

Respecting the seasonal variation, we found that the maximum number of cases, 141(39.60\%), were reported in July to September 14(15.55\%) cases, i.e., the monsoon season in this part of the country (Figure 4). Similar findings were mentioned by Tanuj [12]; they noted that the peak incidence of suicidal hanging among males was in June $(n=8,15.1 \%)$ and for females in September $(n=5$, 29.4\%). However, Waghmare et al. [9] argued that relatively fewer cases occurred in monsoon.

By locality, most of the cases $226(60 \%)$ of hanging came from the urban locality (Table 1). These findings were similar to Nattapong Tulapunt and associates [17].
One of the reasons for this finding is since urban residents experience high pressures of competition, especially in working ages [17]. Vijayakumari [18] reported that a private home or apartment is most common for committing suicide by hanging (207 cases, $84.8 \%$ ). This is probably due to the private environment and easy availability of different ligature materials at home [18].

By occupation, most of the deceased were employed $178(50 \%)$ cases, closely followed by $63(17.69 \%)$ cases of unemployed, 50(14.04\%) cases were housewives, $43(12.07 \%)$ students, and only $22(6.17 \%)$ cases were agriculturist (Figure 5). Sharija et al. [16] suggested that the majority of male victims were manual laborers $(45 \%)$;

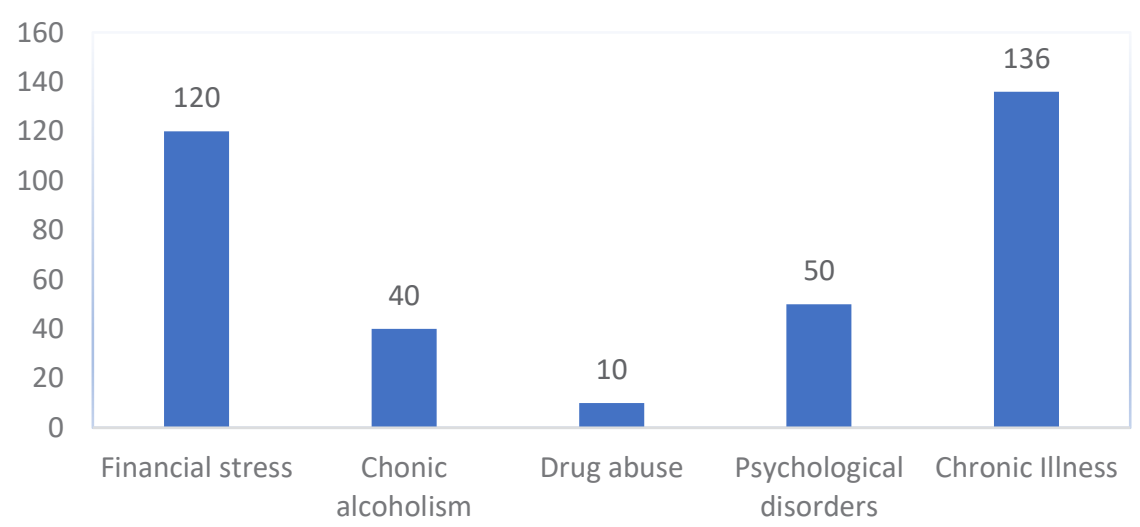

Figure 6. Predisposing factors for the victims to commit hanging $(n=356)$ 


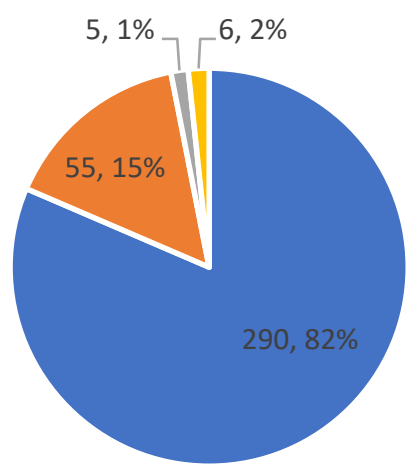

- Hindu $\square$ Muslim $\square$ Christian $\square$ Others (Sikh, Jains, Buddhist etc)

Figure 7. Hanging cases according to religion of the victims $(n=356)$ International Journal of
Medical Toxicology \& Forensic Medicine

Table 4. Distribution according to time of the incident

\begin{tabular}{cc}
\hline Time of Incident & No. of Cases $(\mathbf{n}=\mathbf{3 5 6})$ \\
\hline Early Morning & 28 \\
Morning & 109 \\
\hline Mid-Day & 46 \\
\hline Evening & 85 \\
\hline Night & 88 \\
\hline
\end{tabular}

International Journal of
Medical Toxicology \& forensic Medicine

the majority of females were housewives (53.8\%). Only a tiny proportion of females were working women in society. Unemployed persons constituted $15.5 \%$ of the victims, probably due to the lack of social/financial support. The increased stress of daily life faced by lower socioeconomic status could have been the precipitating event. Rajesh et al. [19] reported that 514(82.90\%) cases were of farmers, followed by housewives 55(8.87\%).
We found that the predisposing factor for suicide by hanging was due to chronic illness in 136(38.20\%) cases, closely followed by financial stress in 120(33.70\%); however, substances abuse was a factor in only $10(2.80 \%)$ cases (Figure 6). Similar findings were noted in a study conducted by Waghmare et al. [9], reporting that ill health due to chronic disease contributes to the cause of suicide. However, Sharija et al. [16] reported chronic alcoholism

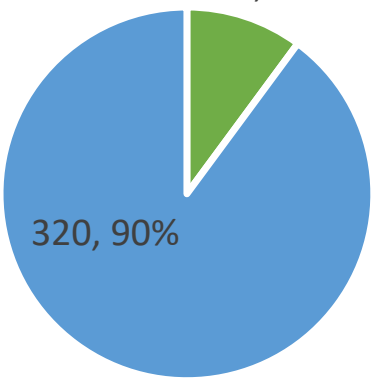

\section{- Suicide note present $\quad$ Suicide note absent}

Figure 8. Distribution of cases based on availability of Suicide note $(n=356)$

International Journal of International Journal of
Medical Toxicology \& Forensic Medicine 
as a predisposing factor in males $(76.1 \%)$. Kerala state in India is infamously renowned for high alcohol consumption rate when compared to the other major states of the country. Therefore, this finding could reflect the ill effects of increased alcohol consumption.

In our study, out of a total of 356 hanging cases, $290(82 \%)$ cases belong to the Hindu religion, while $55(15 \%)$ cases were Muslims (Figure 7). Studies conducted by Shetty [20]. we reported similar findings. However, how significant it is related to the sociodemographic profile of the victims of hanging cases clearly cannot be pointed out; however, the higher the community in the region, the maximum will be the cases.

In most cases $247(69.38 \%$ ) in our study belonged to the lower socioeconomic status, followed by middle class $102(28.65 \%$ ) of total cases (Table 2). Ashok Kumar et al. [10]. indicated that, with the increasing disparity between the poor and the rich and due to high ambitions, these victims fall short of their expectations and then commit suicide by hanging. Out of the 356 cases, most victims, $277(77.80 \%)$, belong to the nuclear family, while the $79(22.19 \%$ ) cases belong to the joint family (Table 3 ). Similar findings were observed in other studies [10-20].

In our study, the morning was the most preferred time for committing suicide accounting for 109(30.61\%) cases, followed by $88(24.71 \%)$ cases in the night and $85(23.87 \%)$ cases in the evening. The most common period for hanging was daytime. This may be because

hanging victims were usually found during the day and because the time of death was sometimes recorded as the time the body was found [10-17]. In our study, most of the cases 320(90\%) cases left no suicide note. Similar findings were noted by Nattapong Tulapunt and associates [17].

\section{Conclusion}

Hanging cases are increasing worldwide, and most of these cases are suicidal. As reported in many studies, factors such as poverty, lack of job, family problems, defamation, social withdrawal, and alcoholism are the main reason for hanging. Hanging as a method of suicide is difficult to prevent; however, the careful screening of susceptible persons, careful watch and monitoring of their behavior, and psychological counseling can reduce suicide. More suicide prevention options exist within controlled environments. A well-designed and comprehensive program is required to identify the causative factors and prevent suicidal behaviors. Appropriate education, influencing the media in their portrayal of suicidal news, reporting methods, the involvement of young generations in suicide prevention campaigns may reduce the rate of suicidal death by hanging in the future.

\section{Ethical Considerations}

\section{Compliance with ethical guidelines}

The confidentiality of patients' information was maintained when the data were obtained from the medical records. All guidelines of the Declaration of Helsinki were observed in all study stages. Ethical approval was obtained from the University Ethics Committee.

\section{Funding}

This research did not receive any grant from funding agencies in the public, commercial, or non-profit sectors.

\section{Author's contributions}

All authors equally contributed to preparing this article.

\section{Conflict of interest}

The authors declared no conflict of interest.

\section{Acknowledgments}

We appreciate the assistance of the Department of Forensic Medicine and Toxicology, VIMS, Ballari, India.

\section{References}

[1] Reddy NKS. The essentials of forensic medicine \& toxicology. India: Jaypee Brothers Medical Publishers Pvt. Limited; 2017. https://www.google.com/books/edition/Essentials_ of_Forensic_Medicine_and_Toxi/DW_3xQEACAAJ?hl=en

[2] Nandy A. Principle of forensic medicine including toxicology. Kolkata: New Central Book Agency (P) Limited; 2007. https://www.google.com/books/edition/Principles_Of_ Forensic_Medicine_Includin/_dAKd3b6pUgC?hl=en

[3] Mohanty S, Sahu G, Mohanty MK, Patnaik M. Suicide in India: A four-year retrospective study. J Forensic Leg Med. 2007; 14(4):185-9. [DOI:10.1016/j.jcfm.2006.05.007] [PMID]

[4] Saukko P, Knight B. Knight's Forensic Pathology ( $3^{\text {rd }}$ ed.). CRC Press; 2004. https://www.google.com/books/edition/ Knight_s_Forensic_Pathology/o9zQMgEACAAJ?hl=en

[5] Pillay VV. Textbook of Forensic Medicine and Toxicology 2019. EDUCA Books; 2019. https://www.google.com/ books/edition/Textbook_of_Forensic_Medicine_and_Toxico/UJFDxQEACAAJ?hl=en 
[6] Mukherjee JB. Forensic Medicine and Toxicology. Calcutta: Academic Publishers; 1981. p. 453-91. http://academicpublishers.in/site/book_details/Medical-Science/j-b-mukherjee-forensic-medicine-and-toxicology

[7] National Crime Records Bureau. Accidental deaths and suicides in India, 2000. New Delhi: Government of India 2003. https://www.google.com/books/edition/Accidental_ Deaths_and_Suicides_in_India/aN6mQwAACAAJ?hl=en

[8] Thakur RK. Hanging the first option for killing self in 2019: NCRB data [Internet]. 2020 [Updated 2020 September 8]. Available from: https://www.newindianexpress.com/nation/2020/sep/08/hanging-the-first-option-for-killing-selfin-2019-ncrb-data-2194007.html

[9] Waghmare PB, Chikhalkar BG, Nanandkar SD. Analysis of asphyxial deaths due to hanging. J Indian Acad Forensic Med. 2014; 36(4):343-5. https://www.indianjournals.com/ ijor.aspx? target $=$ ijor:jiafm\&volume $=36 \&$ issue $=4 \&$ article $=002$

[10] Kumar SA, Ranjan NS. Newer trends in hanging deaths. J Indian Acad Forensic Med. 2012; 34(1):37-9. https:/ / www. indianjournals.com/ijor.aspx?target $=$ ijor:jiafm\&volume $=34$ \&issue $=1$ \&article $=010$

[11] Reddy PS, Kumar RR, Rudramurthy. Asphyxial deaths at district hospital, Tumkur, A retrospective study. J Indian Acad Forensic Med. 2012; 34(2):146-7. https://www.indianjournals.com/ijor.aspx?target=ijor:jiafm\&volume $=34 \&$ issue $=$ 2\&article $=014$

[12] Tanuj K. Day, week and month of suicide by hanging. J Indian Acad Forensic Med. 2008; 30(4):202-6. https:/ /www. indianjournals.com/ijor.aspx?target $=$ ijor:jiafm $\&$ volume $=30$ \&issue $=4$ \&article $=004$

[13] Abd-Elwahab Hassan D, Ghaleb SS, Kotb H, Agamy M, Kharoshah M. Suicidal hanging in Kuwait: Retrospective analysis of cases from 2010 to 2012. J Forensic Leg Med. 2013; 20(8):1118-21. [DOI:10.1016/j.jflm.2013.09.021] [PMID]

[14] Uzün I, Büyük Y, Gürpinar K. Suicidal hanging: Fatalities in Istanbul retrospective analysis of 761 autopsy cases. J Forensic Leg Med. 2007; 14(7):406-9. [DOI:10.1016/j.jflm.2007.01.002] [PMID]

[15] Byard RW, Klitte A, Gilbert JD. Changing patterns of female suicide: 1986- 2000. J Clin Forensic Med. 2004; 11(3):123-8. [DOI:10.1016/j.jcfm.2003.12.002] [PMID]

[16] Sharija S, Sreekumari K, Geetha O. Epidemiological profile of suicide by hanging in southern parts of Kerala: An autopsybased study. J Indian Acad Forensic Med. 2011; 33(3):237-40. https://www.indianjournals.com/ijor.aspx?target=ijor:jiafm $\&$ volume $=33 \&$ issue $=3 \&$ article $=012$

[17] Tulapunt N, Phanchan S, Peonim V. Hanging fatalities in central Bangkok, Thailand: A 13-year retrospective study. medicine. Clin Med Insights Pathol. 2017; 10:1179555717692545. [DOI:10.1177/1179555717692545] [PMID] [PMCID]

[18] Vijayakumari N. Suicidal hanging: A prospective study. J Indian Acad Forensic Med. 2011; 33(4):353-5. https:/ / www. indianjournals.com/ijor.aspx?target $=$ ijor:jiafm $\&$ volume $=33$ \&issue $=4 \&$ article $=017$

[19] Rajesh K, Vishwajeet P. Changing trends of suicides in Marathwada region of Maharashtra in central India: A retrospective study. Indian j Forensic Med Pathol. 2017; 10(4):253-7. [DOI:10.21088/ijfmp.0974.3383.10417.1]
[20] Shetty CK. Suicide cases in Manipal, South India: An autopsy study. Int J Forensic Sci Pathol. 2014; 2(7):50-6. [DOI:10.19070/2332-287X-1400015] 